\title{
GENDER DIFFERENCES IN PREDICTORS OF SELF-MEDICATION WITH TRANQUILLIZERS AND SLEEPING PILLS: RESULTS OF THE POPULATION-BASED STUDY IN SERBIA
}

\author{
RAZLIKE MED SPOLOMA PRI KAZALNIKIH SAMOZDRAVLJENJA S POMIRJEVALI \\ IN ZDRAVILI ZA SPANJE: REZULTATI POPULACIJSKE ŠTUDIJE V SRBIJI
}

\author{
Katica TRIPKOVIĆ ${ }^{*}$, Milena ŠANTRIĆ MILIĆEVIĆ ${ }^{2}$ Marina ODALOVIĆ ${ }^{3}$
}

\begin{abstract}
${ }^{1}$ City Institute of Public Health Belgrade, Planning, Analysis and Organization of Health-Care, Bulevar Despota Stefana 54a, 11000 Belgrade, Serbia

'University of Belgrade, Faculty of Medicine, Institute of Social Medicine, 11000 Belgrade, Serbia 3University of Belgrade, Faculty of Pharmacy, Department of Social Pharmacy and Pharmaceutical Legislation, 11000 Belgrade, Serbia
\end{abstract}

\author{
ABSTRACT \\ Keywords: \\ self-medication, \\ unmet needs, \\ tranquillizers \\ and sleeping \\ pills, predictors, \\ prevalence, gender
}

\section{IZVLEČEK}

Ključne besede: samozdravljenje, nepotešene potrebe, pomirjevala in zdravila za spanje, razširjenost, spol
Background: Previous studies among the Serbian population concluded that the trend of self-medication with tranquillizers and sleeping pills requires deeper study. The objective is to identify gender differences in sociodemographic, health, and health service predictors of self-medication with tranquillizers and sleeping pills in a Serbian population of 15 years old and above.

Methods: This was a population-based, cross-sectional study. Data was extracted from the most recently available results of the Serbian National Health Survey of 2013. Multivariate logistic regression was used to determine independent self-medication predictors.

Results: The study included 14,623 participants, of which $51.77 \%$ were female. While $5.6 \%$ of the females reported self-medication with tranquillizers and sleeping pills, only $2.2 \%$ of males reported such practice $(p<0.001)$. The presence of chronic disease, stress, and physical pain in the last month before the interview was significantly associated with an increased likelihood of self-medication with observed drugs in both genders. Age was the most significant socio-demographic predictor of self-medication in females, while in males it was unemployment. Women of 55-65 years of age showed a greater risk from self-medication with tranquillizers and sleeping pills in comparison to women of $15-24$ years of age $(\mathrm{aOR}=4.75,95 \% \mathrm{Cl}: 1.83-12.33)$. Unemployed males showed a greater tendency for such practice in comparison to employed ( $\mathrm{aOR}=1.86,95 \% \mathrm{Cl}: 1.19-2.91)$.

Conclusion: The findings highlighted predictors of self-medication with tranquillizers and sleeping pills and important differences between genders, which may contribute to the design of gender-sensitive surveillance, identification, and the prevention of such undesirable practices through evidence-based and appropriately tailored public health actions.

Ozadje: Prejšnje raziskave srbskega prebivalstva ugotavljajo, da trend samozdravljenja s pomirjevali in zdravili za spanje potrebuje poglobljeno raziskavo. Cilj: Prepoznati razlike med spoloma pri socialnih, demografskih, zdravstvenih kazalnikih ter kazalnikih zdravstvenih storitev samozdravljenja s pomirjevali in zdravili za spanje pri srbskem prebivalstvu od 15. leta starosti.

Metode: Medsektorska raziskava na podlagi prebivalstva. Podatki so bili zbrani iz najnovejših razpoložljivih rezultatov Srbske nacionalne zdravstvene ankete iz leta 2013. Za določanje neodvisnih kazalnikov samozdravljenja je bila uporabljena multivariantna logistična regresija.

Rezultati: Raziskava vključuje 14.623 sodelujočih, od tega 51,77 \% žensk. Medtem ko je 5,6 \% žensk poročalo o samozdravljenju s pomirjevali in zdravili za spanje, je le $2,2 \%$ moških poročalo o tovrstni praksi ( $p<$ 0,001). Prisotnost kronične bolezni, stresa ali fizične bolečine $v$ zadnjem mesecu pred intervjujem je značilno povezana s povečanjem verjetnosti samozdravljenja s proučevanimi zdravili pri obeh spolih. Starost je najbolj pomemben socialni in demografski kazalnik samozdravljenja pri ženskah, pri moških pa nezaposlenost. Ženske, stare med 55 in 65 let, izkazujejo večje tveganje za samozdravljenje s pomirjevali in zdravili za spanje $v$ primerjavi z ženskami, starimi med 15 in 24 let $(a O R=4,75,95 \% \mathrm{Cl}: 1,83-12,33)$. Nezaposlene ženske so prikazale večjo naklonjenost tovrstni praksi v primerjavi z zaposlenimi $(a O R=1,86,95 \% \mathrm{Cl}$ : 1,19-2,91).

Zaključek: Ugotovitve izpostavljajo kazalnike samozdravljenja s pomirjevali in zdravili za spanje in pomembne razlike med spoloma, kar lahko prispeva $k$ oblikovanju nadzora na podlagi spola ter prepoznavanje in preprečevanje tovrstnih neželenih praks z ustrezno prilagojenimi promocijami javnega zdravja. 


\section{INTRODUCTION}

The World Health Organization (WHO) has defined the term 'responsible self-medication' as a practice in which individuals treat their illnesses and conditions with medicines that have been approved for use and are available without a prescription, but are also safe and effective when used as directed (1). In spite of the many benefits of responsible self-medication, actual practice in medication use provides opportunities for improper use of medicines, e.g. self-medication with drugs approved as prescription drugs. This practice was recognized as a typical example of drug misuse by the WHO (2). Accordingly, preventative actions are of high importance as they align with potential risks at the individual and community level, where such practice induces a higher prevalence of drug-induced diseases and subsequent increases in public expenditure (3-5).

It was recorded that the practice of self-medication in Serbia includes not only over-the-counter medicines but also prescription medicines. Luković et al. reported that medical students used sedatives (13\%) and antidepressants (2\%) without a doctor's prescription in the year previous to the study taking place (6). This practice is very worrying as it correlates to a wide range of adverse effects such as changes in blood pressure, heart rate, sweating, insomnia (7), sedation (8), and sexual dysfunction (9). Moreover, benzodiazepines are identified as a contributing factor in suicides and poisoning deaths, while withdrawal and dependence of benzodiazepines have raised particular concerns $(8,10)$. Since self-medication with sedatives and antidepressants could be a threat to both individual and public health, this phenomenon should be investigated in detail to reveal the most common causes and strategies for reducing such practice.

Studies on predictors of self-medication with tranquillizers and sleeping pills are rare and commonly associated with the investigation of alcohol and opioid abuse (11-13). It was shown that self-medication of anxiety disorders was associated with lower mental health-related quality of life and a higher use of health services (14). The timely screening and treatment of mental health problems are well-recognised preventive factors for substance-use disorders (15). Additionally, the lack of medicines was revealed as primary unmet healthcare needs among patients with mental health problems (16). It was also shown that adolescents who were prescribed anxiolytics during their lifetime were 12 times more likely to use another's anxiolytic medication, which was recognized as a risk factor with significant implication to later substance-use problems (17). The abuse of tranquillizers or sedatives in adults was shown to be directly associated with a higher prevalence of substance use disorder later on (18). Female gender was a well-confirmed risk factor for self-medication in general (19-24). Up-to-date research suggests that females also seem to be at a higher risk from self-medication with tranquillizers and sleeping pills, but such studies are rare (25). Studies that investigated predictors of self-medication with tranquillizers and sleeping pills only in males are missing. Highlighting the prevalence, determinants and gender differences in selfmedication with tranquillizers and sleeping pills could be very useful in the creation of targeted interventions and prevention of such addictive disorders. The aim of the current analysis is to identify gender-related sociodemographic, health and health service associated predictors in self-medication with tranquillizers and sleeping pills in the Serbian population.

\section{METHODS}

\subsection{Study Design, Sample, and Setting}

This was a population-based, cross-sectional study. A study sample was generated from the Serbian population aged 15 years and above through the Serbian National Health Survey 2013, conducted during the period from October 7th to December 30th, 2013. Sampling methodology along with the study protocol was in line with the European Health Interview Survey (EHIS wave 2) Methodological Manual instructions and is described in detail elsewhere (26). Out of 16,474 registered household members aged 15 years and above, 14,623 accepted to be interviewed, which created the response rate of $88.9 \%$ (26).

The survey was approved by the Ethical Board of the National Institute of Public Health of the Republic of Serbia and the Ministry of Health. Specially trained interviewers were obliged to provide the survey participants with a printed document informing them about the survey (Information about the Survey).

\subsection{Data Source and Variables}

A face-to-face self-reported questionnaire was used for data collection. From the pool of data of the National Health Survey 2013, the data related to self-medication with tranquillizers and sleeping pills was extracted. Selfmedication was presented to respondents as the usage of drugs not prescribed by the doctor, meaning that the respondent used the medicine on his/her own initiative or in consultation with the doctor but did not receive a prescription in the two weeks before the interview. The dependent variable, "self-medication with tranquillizers and sleeping pills", was defined as a dichotomous variable with two potential answers, "no" and "yes", where "no" was observed as a reference category within the statistical analysis. Benzodiazepine drugs, anxiolytics (e.g. diazepam, bromazepam, lorazepam, prazemap, alprazolam) and hypnotics (e.g. nitrazepam) were considered as mostly used tranquillizers and sleeping pills. 
The study had the following three sets of independent variables, which were mostly measured by the multiple choice questions; (i) socio-demographic characteristics (age, gender [male/female]), level of education (no formal education/primary school/secondary school/ undergraduate studies/postgraduate studies), employment status (employed/unemployed, including house wife activities and working inability/pupil or student/retiree), (ii) health-related characteristics (self-perceived general health (very good/good/fair/ poor/very poor), presence of chronic disease (yes/no), physical pain and its intensity in the last four weeks prior to the interview (no/yes, not more than others/ yes, more than others/yes, unbearable), stress exposure in the last four weeks (no/very $\mathrm{mild} / \mathrm{mild} /$ moderate/ severe[very severe]), and (iii) healthcare system-related characteristics (unmet healthcare needs in the past 12 months due to the long waiting time for health service and distance or transportation barriers (no/no need for healthcare/yes), satisfaction with public healthcare service and satisfaction with private healthcare service (very satisfied/satisfied/neither satisfied nor dissatisfied/ dissatisfied/very dissatisfied).

\subsection{Statistical Analysis}

Descriptive statistics were used to analyse study sample characteristics. The prevalence and 95\% confidence interval $(\mathrm{Cl})$ of self-medication among males and females was calculated separately. The crude odds ratio (OR) with 95\% confidence interval $(\mathrm{Cl})$ was used to analyse univariate associations between the independent (potential explanatory) variables with the dependent variable ("self-medication with tranquillizers and sleeping pills"). Variables found to be significantly associated with selfmedication in the univariate analysis were included in the multivariate logistic regression models.

The multivariate logistic regression analysis identified potential, gender-related, predictors of self-medication with tranquillizers and sleeping pill using an adjusted odds ratio (aOR) with $95 \% \mathrm{Cl}$.

Statistical significance in all analyses was deemed likely if the computed probability value was $<0.05$. Data analysis was performed by using Statistical Package for Social Sciences (SPSS) software (SPSS 18.0 for Windows, SPSS Inc., Chicago, IL, USA).

\section{RESULTS}

Females and males have been almost equally distributed in the study sample; $7,570(51.77 \%)$ and 7,053 (48.23\%), respectively. In sum, 579 (4\%; $95 \% \mathrm{Cl}: 3.6-4.3)$ of the study population reported self-medication with tranquillizers and sleeping pills. While 421 of the female population (5.6\%, $95 \% \mathrm{Cl}: 5.0-6.1)$, only 158 of the male population $(2.2 \%, 95 \% \mathrm{Cl}: 1.9-2.6)$ reported such self-medication practice $(\mathrm{p}<0.001)$.

Further analysis has shown that self-medication with selected drugs among females (Table 1 ) and males (Table 2) was significantly associated with investigated sociodemographic and health-related characteristics, as well as unmet healthcare needs in the past 12 months due to the long waiting time for health service, distance or transportation barriers. However, it was not associated with the satisfaction with public and private health service among females, and with education and satisfaction with private healthcare service among males $(p>0.05)$. 
Table 1. Prevalence of self-medication with tranquillizers and sleeping pills in the Serbian female population and association with selected socio-demographic, health, and healthcare system characteristics, $n=7,570$.

\begin{tabular}{|c|c|c|c|c|}
\hline Female population characteristics & Prevalence of TSP self-medication, (\%) & $95 \% \mathrm{Cl}$ & Crude OR & $95 \% \mathrm{Cl}$ \\
\hline Female TSP users & 5.6 & $5.0-6.1$ & & \\
\hline \multicolumn{5}{|l|}{ Age (years) } \\
\hline $15-24$ & 1.0 & 0.4-1.7 & - & \\
\hline $25-34$ & 2.4 & $1.5-3.2$ & 2.20 & $1.07-4.54$ \\
\hline 35-44 & 4.0 & 2.9-5.1 & 3.85 & $1.96-7.60$ \\
\hline $45-54$ & 6.6 & $5.2-8.0$ & 6.51 & $3.40-12.49$ \\
\hline $55-64$ & 10.2 & $8.6-11.8$ & 10.43 & $5.53-19.67$ \\
\hline $65-74$ & 7.0 & $5.3-8.7$ & 6.94 & $3.58-13.44$ \\
\hline$\geq 75$ & 6.6 & 4.9-8.3 & 6.53 & $3.34-12.76$ \\
\hline
\end{tabular}

\section{Employment status}

Employed

Unemployed

Pupil/Student

Retiree

Education

No formal education/ Primary school

Secondary school

Undergraduate/Postgraduate studies

\section{Self-assessment of health status}

Very good/Good/Fair

Poor/Very poor

\section{Presence of chronic disease}

No

Yes

Exposure to stress during four weeks prior to the interview No/Yes, not more than others

Yes, more than others/Yes, unbearable

13.4

3.2-4.9

5.1-6.9

0.4-1.9

1.49

0.28

6.7-9.0

2.01

5.7-7.5

4.6-6.0

0.79

0.58

0.64-0.97

$2.8-5.0$

4.1-5.1

8.0-11.0

2.16

$1.75-2.67$
$1.3-2.2$

7.4-9.0

3.8-4.8

$11.4-15.4$

2.8-3.9

6.2-8.4

$7.8-11.0$

2.26

2.97

1.79-2.85

9.4

Severe/Very severe

5.9

2.5 No

No need for healthcare

8.6

$1.7-3.3$

0.41

0.30-0.57

Yes

$6.9-10.2$

1.49

1.17-1.91

Unmet healthcare needs in the past 12 months due to distance or transportation barriers

No

No need for healthcare

6.1

2.7

5.4-6.7

Yes

10.6

2.0-3.5

0.44

$0.32-0.60$

7.5-13.7

1.83

$1.30-2.58$

Satisfaction with public health service

Very satisfied/Satisfied

5.3

Neither satisfied nor dissatisfied

5.8

$4.6-6.0$

Dissatisfied/Very dissatisfied

6.3

4.8-6.9

1.11

$0.88-1.41$

6.3

5.1-7.5

1.21

$0.94-1.56$

Satisfaction with private health service

Very satisfied/Satisfied

4.7

Neither satisfied nor dissatisfied

5.6

Dissatisfied/Very dissatisfied

7.1

4.0-5.5

4.2-7.0

4.3-9.9

1.20

1.55

$0.87-1.64$

$0.98-2.43$

Notes: significant findings where $\mathrm{p}<0.05$ are marked in bold: Abbreviations: TSP- tranquillizers and sleeping pills,

$\mathrm{Cl}$ - Confidence Interval, OR- Odds Ratio 
Table 2. Prevalence of self-medication with tranquillizers and sleeping pills in the Serbian male population and association with selected socio-demographic, health, and healthcare system characteristics, $n=7,053$.

\begin{tabular}{|c|c|c|c|c|}
\hline Female population characteristics & Prevalence of TSP self-medication, (\%) & $95 \% \mathrm{Cl}$ & Crude OR & $95 \% \mathrm{Cl}$ \\
\hline Female TSP users & 2.2 & $1.9-2.6$ & & \\
\hline \multicolumn{5}{|l|}{ Age (years) } \\
\hline $15-24$ & 0.4 & $0.1-0.7$ & - & - \\
\hline $25-34$ & 0.9 & $0.4-1.5$ & 2.72 & $0.82-9.04$ \\
\hline $35-44$ & 2.0 & $1.2-2.8$ & 5.86 & $1.91-18.07$ \\
\hline $45-54$ & 2.8 & $1.8-3.7$ & 8.31 & $2.77-24.99$ \\
\hline $55-64$ & 3.1 & $2.2-4.1$ & 9.34 & $3.14-27.78$ \\
\hline $65-74$ & 4.1 & 2.7-5.6 & 12.54 & $4.15-37.86$ \\
\hline$\geq 75$ & 3.3 & $1.8-4.9$ & 10.09 & $3.20-31.80$ \\
\hline \multicolumn{5}{|l|}{ Employment status } \\
\hline Employed & 1.4 & $1.0-1.8$ & - & - \\
\hline Unemployed & 2.9 & $2.1-3.7$ & 2.08 & $1.37-3.16$ \\
\hline Pupil/Student & 0.5 & $0.1-0.9$ & 0.29 & $0.09-1.00$ \\
\hline Retiree & 3.6 & $2.7-4.5$ & 2.63 & $1.76-3.91$ \\
\hline \multicolumn{5}{|l|}{ Education } \\
\hline No formal education/ Primary school & 2.0 & $1.3-2.6$ & - & - \\
\hline Secondary school & 2.4 & $2.0-2.9$ & 1.25 & $0.84-1.87$ \\
\hline Undergraduate/Postgraduate studies & 2.0 & $1.2-2.8$ & 1.00 & $0.58-1.72$ \\
\hline \multicolumn{5}{|l|}{ Self-assessment of health status } \\
\hline Very good/Good/Fair & 1.6 & $1.3-1.9$ & - & \\
\hline Poor/Very poor & 6.9 & $5.1-8.6$ & 4.52 & $3.24-6.30$ \\
\hline \multicolumn{5}{|l|}{ Presence of chronic disease } \\
\hline No & 0.6 & $0.3-0.9$ & - & \\
\hline Yes & 4.0 & $3.3-4.7$ & 6.73 & $4.30-10.53$ \\
\hline \multicolumn{5}{|c|}{ Exposure to stress during four weeks prior to the interview } \\
\hline No/Yes, not more than others & 1.5 & $1.2-1.8$ & - & \\
\hline Yes, more than others/Yes, unbearable & 8.5 & $6.4-10.6$ & 6.03 & $4.32-8.40$ \\
\hline \multicolumn{5}{|c|}{ Physical pain during four weeks prior to the interview } \\
\hline No/Very mild & 1.0 & $0.7-1.2$ & - & \\
\hline Mild/Moderate & 5.2 & $4.0-6.3$ & 5.57 & $3.87-8.03$ \\
\hline Severe/Very severe & 5.7 & $3.8-7.6$ & 6.18 & $3.95-9.66$ \\
\hline \multicolumn{5}{|c|}{ Unmet healthcare needs in the past 12 months due to a long waiting time for health service } \\
\hline No & 2.5 & $2.0-3.0$ & - & \\
\hline No need for healthcare & 0.7 & 0.3-1.0 & 0.27 & $0.16-0.45$ \\
\hline Yes & 6.4 & 4.6-8.3 & 2.72 & 1.89-3.92 \\
\hline \multicolumn{5}{|c|}{ Unmet healthcare needs in the past 12 months due to distance or transportation barriers } \\
\hline No & 2.8 & $2.3-3.3$ & - & \\
\hline No need for healthcare & 0.6 & $0.3-0.9$ & 0.22 & $0.13-0.38$ \\
\hline Yes & 10.2 & $6.1-14.4$ & 4.00 & 2.48-6.47 \\
\hline \multicolumn{5}{|l|}{ Satisfaction with public health service } \\
\hline Very satisfied/Satisfied & 2.0 & $1.5-2.5$ & - & \\
\hline Neither satisfied nor dissatisfied & 2.5 & $1.8-3.2$ & 1.25 & $0.86-1.82$ \\
\hline Dissatisfied/Very dissatisfied & 3.4 & $2.3-4.4$ & 1.68 & $1.13-2.50$ \\
\hline \multicolumn{5}{|l|}{ Satisfaction with private health service } \\
\hline Very satisfied/Satisfied & 2.6 & $2.0-3.3$ & - & \\
\hline Neither satisfied nor dissatisfied & 2.2 & $1.3-3.1$ & 0.82 & $0.51-1.33$ \\
\hline Dissatisfied/Very dissatisfied & 4.0 & $1.9-6.1$ & 1.53 & $0.85-2.77$ \\
\hline
\end{tabular}

Notes: significant findings where $\mathrm{p}<0.05$ are marked in bold: Abbreviations: TSP- tranquillizers and sleeping pills,

$\mathrm{Cl}$ - Confidence Interval, OR- Odds Ratio 


\subsection{Predictors of Self-Medication with Tranquillizers and Sleeping Pills}

Multivariate analysis revealed several independent predictors of self-medication with tranquillizers and sleeping pills common for females and males. In both populations, health-related characteristics, including the presence of chronic disease, stress exposure and the presence of physical pain in the four weeks prior to the interview, were significantly associated with an increased likelihood of the use of tranquillizers and sleeping pills without a doctors' prescription (Table 3 and Table 4).
However, significant differences in socio-demographic predictors between females and males were shown. The age categories of 45-54, 55-64 and 65-74 years were independent predictors of a higher likelihood for selfmedication with tranquillizers and sleeping pills among females, versus males. Concurrently, unemployment status was revealed as an independent predictor of such practices for males, whereas employment was not significantly associated with self-medication with tranquillizers and sleeping pills in females (Table 3, Table 4).

Table 3. Potential predictors of self-medication with tranquillizers and sleeping pills among selected socio-demographic, health, and healthcare system characteristics in the Serbian female population, $n=7,570$.

\begin{tabular}{|c|c|c|}
\hline Female population characteristics & Adjusted OR & $95 \% \mathrm{Cl}$ \\
\hline \multicolumn{3}{|l|}{ Age (years) } \\
\hline $15-24$ & - & \\
\hline $25-34$ & 1.86 & $0.71-4.84$ \\
\hline $35-44$ & 2.63 & $1.00-6.88^{*}$ \\
\hline $45-54$ & 3.37 & $1.30-8.72$ \\
\hline $55-64$ & 4.75 & $1.83-12.33$ \\
\hline $65-74$ & 2.96 & $1.10-7.97$ \\
\hline$\geq 75$ & 2.62 & $0.96-7.14$ \\
\hline \multicolumn{3}{|l|}{ Employment status } \\
\hline Employed & - & \\
\hline Unemployed & 1.14 & $0.84-1.55$ \\
\hline Pupil/Student & 1.13 & $0.40-3.25$ \\
\hline Retiree & 1.03 & $0.72-1.48$ \\
\hline \multicolumn{3}{|l|}{ Education } \\
\hline No formal education/Primary school & - & \\
\hline Secondary school & 1.06 & $0.83-1.35$ \\
\hline Undergraduate/Postgraduate studies & 0.84 & $0.58-1.21$ \\
\hline \multicolumn{3}{|l|}{ Self-assessment of health status } \\
\hline Very good/Good/Fair & - & \\
\hline Poor/Very poor & 0.87 & $0.67-1.13$ \\
\hline
\end{tabular}

\section{Presence of chronic disease}

No

Yes

Exposure to stress in the four weeks prior to interview No/Yes, not more than others

Yes, more than others/Yes, unbearable

Physical pain in the four weeks prior to interview No/Very mild

Mild/Moderate

Severe/Very severe

Unmet healthcare needs in the past 12 months due to a long waiting time for health service No
No need for healthcare
0.69
$0.33-1.43$
Yes
1.09
$0.82-1.44$

Unmet healthcare needs in the past 12 months due to distance or transportation barriers

No

No need for healthcare

1.15

0.78-1.71

Yes

1.07

$0.54-2.13$

Notes: ${ }^{*} \mathrm{p}=0.05$; significant findings where $\mathrm{p}<0.05$ are marked in bold; all variables significantly associated in univariate analysis were included in multivariate analysis. Abbreviations: OR- Odds Ratio; $\mathrm{Cl}$ - Confidence Interval 
Table 4. Potential predictors of self-medication with tranquillizers and sleeping pills among selected socio-demographic, health, and healthcare system characteristics in the Serbian male population, $n=7,053$.

\begin{tabular}{lcc}
\hline Male population characteristics & Adjusted OR & $95 \% \mathrm{Cl}$ \\
\hline Age (years) & & - \\
\hline $15-24$ & 2.36 & $0.53-10.56$ \\
$25-34$ & 3.62 & $0.81-16.27$ \\
$35-44$ & 3.66 & $0.82-16.31$ \\
$45-54$ & 3.08 & $0.68-13.85$ \\
$55-64$ & 3.95 & $0.80-19.40$ \\
$\geq 75-74$ & 3.17 & $0.62-16.17$
\end{tabular}

\section{Employment status}

Employed

Unemployed

\section{Self-assessment of health status}

Very good/Good/Fair

Poor/Very poor

\section{Presence of chronic disease}

No

Yes

Exposure to stress in the four weeks prior to interview No/Yes, not more than others

Yes, more than others/Yes, unbearable

Physical pain in the four weeks prior to the interview No/Very mild

Mild/Moderate

Severe/Very severe

Unmet healthcare needs in the past 12 months due to the long waiting time for health service No
No need for healthcare
1.94
0.52-7.25
1.43
$0.93-2.18$

Yes

Unmet healthcare needs in the past 12 months due to distance or transportation barriers

No
No need for healthcare
0.28
0.08-1.06

Yes

1.55

$0.87-2.76$

Satisfaction with public health service

Very satisfied/Satisfied

Neither satisfied nor dissatisfied

1.09

0.73-1.63

Dissatisfied/Very dissatisfied

0.99

$0.64-1.54$

Notes: significant findings where $p<0.05$ are marked in bold; all variables significantly associated in univariate analysis were included in multivariate analysis. Abbreviations: OR- Odds Ratio; Cl- Confidence Interval 


\section{DISCUSSION}

Based on our knowledge, this is a rare study highlighting gender differences in predictors of self-medication with tranquillizers and sleeping pills controlled for sociodemographic factors, health status and satisfaction with the healthcare system. Our study has shown that self-medication is a more frequent practice among the female population compared to males in cases of selfmedication with tranquillizers and sleeping pills. Healthrelated factors (chronic disease and physical pain) and environmental stress were revealed as independent predictors of self-medication with observed drugs in both men and women. However, gender differences have been shown through two discriminatory factors, age, and employment status. While an age of above 45 years has been revealed as a strong predictor of self-medication with tranquillizers and sleeping pills in women, a similar effect was not confirmed among males. On the contrary, unemployment has been shown as a significant determinant of self-medication with tranquillizers and sleeping pills in males, but without significant influence in females.

Several previous studies investigated the determinants of regularly prescribed medication use for depression, anxiety, stress, and sleep problems in the female population $(27,28)$. They also found age, stress, and physical pain as predictors of regular use of hypnotics/ anxiolytics/sedatives, as well as other predictors like social tension, hormone replacement therapy, headaches, palpitations, mood swings or increased muscular tension, anger, duration of symptoms lasting longer than one week, consulting a specialist, and mental health-related quality of life. In line with the abovementioned predictive factors, one potential area of intervention may be a focus on timely and proper patient education interventions by healthcare professionals with special warnings about side effects. This may aid in the prevention of future self-medication in women already prescribed drugs for depression, anxiety, stress, or sleeping problems.

This study has also shown that self-medication with tranquillizers and sleeping pills is significantly higher in males and females who have reported chronic diseases and physical pain. Since these patients are most likely already prescribed some other medicines, the possibility of drug-drug interactions is increased. This could be of particular concern if an already prescribed drug is a suppressor of the central nervous system (CNS), because of the well-known CNS suppressive effect of tranquillizers and sleeping pills $(29,30)$. Along with warnings about side effects, patient education interventions should include descriptions of prescribed therapy purposes, with the aim to decrease the rate of therapy duplication or harmful effects.
The results of our study have shown that the risks from self-medication in women increase significantly for those over 45 years of age, which coincides with the start of the menopause. This risk reaches a peak at 55-64 years of age when women predominantly cope with unpleasant menopausal symptoms. Additionally, many with symptoms of non-communicable diseases maintain overwhelming amounts of work and family responsibilities with little to no focus on personal health. The decline of risk starts after 65 years of age, which could be linked to the end of women's working engagement and a decrease in the level of family stress, as well as to the end of the menopause. Most middle-aged women suffer from high demands in personal and professional responsibilities and, accordingly, need specialised support. A similar phenomenon may be observed with unemployed males. In spite of Serbia's many modern ways of thinking about traditional gender roles, some traditional elements continue to dominate within Serbian society. One example is the attitude that males are consistently expected to serve as dominant breadwinners in the family. For this reason, the male population requires additional healthcare support in the effects of unstable employment status. Our study directly confirms previous data that self-medication with tranquillizers is not supported by the hypothesis of gender role convergence and expectations (11).

Environmental stress is the only modifiable factor revealed as the predictor of self-medication with tranquillizers and sleeping pills in both women and men. Although coping with stress is stressful by itself, psychotherapy, meditation, and other relaxing techniques are showed as helpful (31). However, such techniques are not yet widely accepted in the Serbian population. Concurrently, Šantrić-Milićević et al. reported that almost half of the Serbian adult population assessed their mental health as poor and $5 \%$ had diagnosed chronic anxiety or depression (32). Accordingly, well-tailored public health actions, specifically targeting middle-aged women and unemployed males and their ability to cope with stress and pressure in healthy ways, could potentially reduce the high level of self-medication with tranquillizers and sleeping tablets and prevent unwanted behaviours and consequences.

While previous studies have established the association between unmet healthcare needs and self-medication in general or with self-medication with illicit drugs, our results have not confirmed previous findings (15, $21,23,33$ ). Nevertheless, a relatively high prevalence of unmet healthcare needs has been recorded. Unmet healthcare needs due to barriers related to lack of time or geographic accessibility were not potential predictors, perhaps because of the presence of chronic disease that requires continuous monitoring by health professionals. Accordingly, further research should 
explore the relationship between self-medication and the kind of unmet healthcare needs (e.g. prescription of medication, check-up, consultation etc.) and concerning the type of chronic disease condition. This would be of particular benefit for well-targeted preventive measures, especially in developing countries with lower standards and rationalisations of public health expenditures within where the high impacts of unmet healthcare needs could be expected (34).

\subsection{Strengths and Limitations}

The current study has strengths and limitations. One limitation of the study was the inability to assess the cause-consequence relationship between the independent and dependent variables. Instead, we explored potential predictors for self-medication with tranquillizers and sleeping pills. Secondly, the survey data may be burdened with biases due to memory recall, which can lead to an over or underestimation of the study findings. In order to maximise the validity of the findings, participants were asked to give information on medication use for a short period of only two weeks prior to the interview, and for a particular disease out of 17 listed conditions or some other. Additionally, the data was collected in 2013, and it may be that the survey results do not reflect actual practices. However, since that time, there has been no national campaign or other similar public health initiatives with regards to decreasing the use of prescription drug use without a prescription, except in the case of antibiotics. Accordingly, we do not currently expect substitutional differences in the practice of tranquillizers and sleeping pills use. Conducting similar analyses of data from the upcoming National Health Survey will be useful since it will reveal the trend of tranquilizers and sleeping pill use and the subpopulations particularly jeopardised by this behaviour. In the representative sample of the Serbian population of 15 years and above, we were able to determine gender differences in the prevalence and predictors of self-medication with tranquillizers and sleeping pills. The data for the survey was extracted from a sample of the general population. Data related to concrete drugs used in self-medication practices were not collected, which left room for participants to potentially misinterpret tranquillizers and sleeping pills. Additionally, the absence of data related to the exact names of drugs made it impossible to conduct a deeper analysis of particular drugs and drug group usage. The results of this study may be utilised to inform the creation of the survey instrument, which sets out to specifically examine illicit/non-prescription drug and drug groups use. Study findings should be interpreted with these limitations and advantages in mind.

\section{CONCLUSION}

The study findings highlighted different predictors of self-medication with tranquillizers and sleeping pills for men and women. Gender-related socio-demographic differences in predictors were shown (higher age in females and unemployment in males), while the same health-related characteristics were shown as predictors in both genders (presence of chronic disease, physical pain, exposure to stress). While revealed practices and predictors may be useful in improving healthcare professionals' consulting practice, observed gender differences may be utilised to inform the design of gendersensitive surveillance, identification, and prevention of such undesirable practice through well-tailored public health actions.

\section{ACKNOWLEDGMENT}

We are grateful to all participants of the Serbian National Health Survey and to the Ministry of Health of the Republic of Serbia, which made data from the National Health Survey available for further analysis. We are also very grateful to Mr. Ivan Čvorović, MD and Ms. Nikolina Bošković, MPH, for editing of the manuscript.

\section{CONFLICTS OF INTEREST}

The authors declare that no conflicts of interest exist.

\section{FUNDING}

This work was supported by the Ministry of Education, Science and Technological Development of Serbia (grant numbers 175087,41012 ) which had no role in study design, collection, analysis or interpretation of data, writing the manuscript, or in the decision to submit the article for publication.

\section{ETHICAL APPROVAL}

The Serbian National Health Survey 2013 was approved by the Ethical Board of the National Institute of Public Health of the Republic of Serbia and the Ministry of Health. 


\section{REFERENCES}

1. WHO. The role of the pharmacist in self-care and self-medication. Accessed March 10th, 2019 at: http://apps.who.int/medicinedocs/ en/d/Jwhozip32e/3.3.html.

2. WHO. Lexicon of alcohol and drug terms published by the World Health Organization. Accessed March 10th, 2019 at: http://www. who.int/substance_abuse/terminology/who_lexicon/en/.

3. WHO. Guidelines for the regulatory assessment of medicinal products for use in self- medication. Accessed March 10th, 2019 at: http:// apps.who.int/medicinedocs/en/d/Jh1462e/6.html\%23Jh1462e.6.1.

4. Bennadi D. Self-medication: a current challenge. J Basic Clin Pharm. 2013 ;5:19-23. doi: 10.4103/0976-0105.128253.

5. Rezaei M, Safavi ARA, Alavi NM, Kashefi H. Study of self-medication in patients with diabetes using path analysis. J Diabetol. 2015;3(2).

6. Lukovic JA, Miletic V, Pekmezovic T, Trajkovic G, Ratkovic N, Aleksic D, et al. Self-medication practices and risk factors for selfmedication among medical students in Belgrade, Serbia. PLoS One. 2014;9:e114644. doi: 10.1371/journal.pone.0114644.t001.

7. Whiskey E, Taylor D. A review of the adverse effects and safety of noradrenergic antidepressants. J Psychopharmacol. 2013;27(8):7329. doi: 10.1177/0269881113492027.

8. Lader M. Benzodiazepine harm: how can it be reduced? $\mathrm{Br}$ J Clin Pharmacol. 2014 ;77:295-301. doi: 10.1111/j.13652125.2012.04418.x.

9. Montejo AL, Montejo L, Navarro-Cremades F. Sexual side-effects of antidepressant and antipsychotic drugs. Curr Opin Psychiatry. 2015;28:418-23. doi: 10.1097/YCO.0000000000000198.

10. Murphy Y, Wilson E, Goldner EM, Fischer B. Benzodiazepine use, misuse, and harm at the population level in Canada: a comprehensive narrative review of data and developments since 1995. Clin Drug Investig. 2016;36:519-30. doi: 10.1007/s40261-016-0397-8.

11. Bell R, Havlicek PL, Roncek DW. Sex differences in the use of alcohol and tranquillizers: testing a role convergence hypothesis. Am J Drug Alcohol Abuse. 1984;10:551-61.

12. Graham K, Wilsnack SC. The relationship between alcohol problems and use of tranquilizing drugs: longitudinal patterns among American women. Addict Behav. 2000;25:13-28. doi: 10.1016/s03064603(99)00025-8.

13. Votaw VR, Witkiewitz K, Valeri L, Bogunovic O, McHugh RK. Nonmedical prescription sedative/tranquilizer use in alcohol and opioid use disorders. Addict Behav. 2019;88:48-55. doi: 10.1016/j. addbeh.2018.08.010.

14. Robinson JA, Sareen J, Cox BJ, Bolton JM. Correlates of selfmedication for anxiety disorders: results from the National epidemiolgic survey on alcohol and related conditions. J Nerv Ment Dis. 2009;197:873-8. doi: 10.1097/NMD.0b013e3181c299c2.

15. Smith LL, Yan F, Charles M, Mohiuddin K, Tyus D, Adekeye O, et al. Exploring the link between substance use and mental health status: what can we learn from the self-medication theory? J Health Care Poor Underserved. 2017;28:113-31. doi: 10.1353/hpu.2017.0056.

16. Fossey E, Harvey C, Mokhtari MR, Meadows GN. Self-rated assessment of needs for mental health care: a qualitative analysis. Community Ment Health J. 2012;48:407-19. doi: 10.1007/s10597-011-9433-6.

17. Boyd CJ, Austic E, Epstein-Ngo Q, Veliz PT, McCabe SE. A prospective study of adolescents' nonmedical use of anxiolytic and sleep medication. Psychol Addict Behav. 2015;29:184-91. doi: 10.1037/ adb0000026.

18. Boyd CJ, West B, McCabe SE. Does misuse lead to a disorder? The misuse of prescription tranquilizer and sedative medications and subsequent substance use disorders in a U.S. longitudinal sample. Addict Behav. 2018;79:17-23. doi: 10.1016/j.addbeh.2017.11.042.
19. Carrasco-Garrido P, Jiménez-García R, Barrera VH, Gil de Miguel A. Predictive factors of self-medicated drug use among the Spanish adult population. Pharmacoepidemiol Drug Saf. 2008;17:193-9. doi: 10.1002/pds. 1455 .

20. Carrasco-Garrido $P$, Hernández-Barrera $V$, López de Andrés $A$, Jiménez-Trujillo I, Jiménez-García R. Sex-differences on selfmedication in Spain. Pharmacoepidemiol Drug Saf. 2010;19:1293-9. doi: 10.1002/pds.2034.

21. De Melo MN, Madureira B, Ferreira APN, Mendes Z, Miranda Ada C, Martins AP. Prevalence of self-medication in rural areas of Portugal. Pharm World Sci. 2006;28:19-25. doi: 10.1007/s11096-005-2222-y.

22. Du Y, Knopf H. Self-medication among children and adolescents in Germany: results of the National health survey for children and adolescents (KiGGS). Br J Clin Pharmacol. 2009;68:599-608. doi: 10.1111/j.1365-2125.2009.03477.x.

23. Martins PA, Miranda Ada C, Mendes Z, Soares MA, Ferreira P, Nogueira A. Self-medication in a Portuguese urban population: a prevalence study. Pharmacoepidemiol Drug Saf. 2002;11:409-14. doi: 10.1002/ pds.711.

24. Mayer S, Österle A. Socioeconomic determinants of prescribed and non-prescribed medicine consumption in Austria. Eur J Public Health. 2015;25:597-603. doi: 10.1093/eurpub/cku179.

25. Schepis TS, Teter CJ, Simoni-Wastila L, McCabe SE. Prescription tranquilizer/sedative misuse prevalence and correlates across age cohorts in the US. Addict Behav. 2018;87:24-32. doi: 10.1016/j. addbeh.2018.06.013.

26. Insitute of Public Health of Serbia. Results of the National health survey of the Republic of Serbia 2013. Belgrade: Insitute of Public Health of Serbia, 2014.

27. Schofield MJ, Khan A. Predictors of prescribed medication use for depression, anxiety, stress, and sleep problems in mid-aged Australian women. Soc Psychiatry Psychiatr Epidemiol. 2014;49:1835-47. doi: 10.1007/s00127-014-0896-y.

28. Zagozdzon P, Kolarzyk E, Marcinkowski JT. Quality of life and social determinants of anxiolytics and hypnotics use in women in Poland: a population-based study. Int J Soc Psychiatry. 2013;59:296-300. doi: $10.1177 / 0020764012440676$.

29. Jones JD, Mogali S, Comer SD. Polydrug abuse: a review of opioid and benzodiazepine combination use. Drug Alcohol Depend. 2012;125:818. doi: 10.1016/j.drugalcdep.2012.07.004.

30. Lintzeris $\mathrm{N}$, Nielsen S. Benzodiazepines, methadone and buprenorphine: interactions and clinical management. Am J Addict. 2010;19:59-72. doi: 10.1111/j.1521-0391.2009.00007.x.

31. Harvey AG, Gumport NB. Evidence-based psychological treatments for mental disorders: modifiable barriers to access and possible solutions. Behav Res Ther. 2015;68:1-12. doi: 10.1016/j. brat.2015.02.004.

32. Santric-Milicevic M, Jankovic J, Trajkovic G, Terzic-Supic Z, Babic $U$, Petrovic M. Socioeconomic inequalities in mental health of adult population: Serbian national health survey. Balkan Med J. 2016;33:36-44.

33. Tripković K, Nešković A, Janković J, Odalović M. Predictors of selfmedication in Serbian adult population: cross-sectional study. Int J Clin Pharm. 2018;40:627-34. doi: 10.1007/s11096-018-0624-x.

34. Popovic N, Terzic-Supic Z, Simic S, Mladenovic B. Predictors of unmet health care needs in Serbia: analysis based on EU-SILC data. PLoS One. 2017;12:e0187866. doi: 10.1371/journal.pone.0187866. 